\title{
Human Skin Collagenase in Recessive Dystrophic
}

\section{Epidermolysis Bullosa}

\author{
PURIFICATION OF A MUTANT ENZYME FROM FIBROBLAST CULTURES
}

\author{
George P. Stricklin, Howard G. Welgus, and Eugene A. Bauer, Division of \\ Dermatology, Department of Medicine, Washington University School of \\ Medicine, St. Louis, Missouri 63110
}

A B S T R A C T Recessive dystrophic epidermolysis bullosa, a genodermatosis characterized by dermolytic blister formation in response to minor trauma, is characterized by an incresaed collagenase synthesis by skin fibroblasts in culture. Since preliminary studies of partially purified recessive dystrophic epidermolysis bullosa collagenase suggested that the protein itself was aberrant, efforts were made to purify this enzyme to homogeneity, so that detailed biochemical and immunologic comparisons could be made with normal human skin fibroblast collagenase. Recessive dystrophic epidermolysis bullosa skin fibroblasts obtained from a patient documented to have increased synthesis of the enzyme were grown in large scale tissue culture and both serum-free and serum-containing medium collected as a source of collagenase. The recessive dystrophic epidermolysis bullosa collagenase was purified to electrophoretic homogeneity using a combination of salt precipitation, ion-exchange, and gel-filtration chromatography. In contrast to the normal enzyme, the recessive dystrophic epidermolysis bullosa collagenase bound to carboxymethyl-cellulose at $\mathrm{Ca}^{2+}$ concentrations at least 10 times higher than those used with the normal enzyme. Additionally, this enzyme was significantly more labile to chromatographic manipulations, particularly when serum-free medium was used. However, rapid purification from serumcontaining medium yielded a preparation enzymatically equivalent to normal human skin collagenase. Like the normal enzyme, the recessive dystrophic epidermolysis bullosa collagenase was secreted as a set of two closely related zymogens of $\sim 60,000$ and $\sim 55,000$ daltons that could be activated by trypsin to form enzymically active species of $\sim 50,000$ and $\sim$ 45,000 daltons, respectively. Amino acid analysis

Received for publication 3 November 1981 and in revised form 27 January 1982. suggested slight variations between the normal and recessive dystrophic epidermolysis bullosa collagenases. Cyanogen bromide digests demonstrated peptides unique to the enzyme from each source. The recessive dystrophic epidermolysis bullosa proenzyme was significantly more thermolabile at $60^{\circ} \mathrm{C}$ than the normal, a finding that correlated with an approximate fourfold decrease in the affinity of the mutant enzyme for $\mathrm{Ca}^{2+}$, a known activator and stabilizer of human skin collagenase. Aside from the altered affinity for this metal cofactor, kinetic analysis of the structurally altered recessive dystrophic epidermolysis bullosa collagenase revealed that its reaction rates and substrate specificity for human collagen types I-V were identical to those for the normal enzyme. Likewise, enzymes from both sources displayed identical energies of activation and deuterium isotope effects. Antisera were raised to the normal and putatively mutant procollagenases respectively, and, although they displayed a reaction of identity in double diffusion analysis, immunologic differences were present in enzyme inhibition and quantitative precipitation studies. These studies indicate that recessive dystrophic epidermolysis bullosa is characterized by the increased synthesis of an enzymically normal, but structurally aberrant, collagenase.

\section{INTRODUCTION}

Epidermolysis bullosa $(\mathrm{EB})^{1}$ comprises a group of heritable skin disorders characterized by blister formation in response to minor trauma $(1,2)$. The four major varieties-recessive dystrophic EB (RDEB), recessive junctional EB, dominant dystrophic EB, and dominant

\footnotetext{
${ }^{1}$ Abbreviations used in this paper: $\mathrm{CM}$, cellulose, carboxymethylcellulose; EB, epidermolysis bullosa; RDEB, recessive dystrophic epidermolysis bullosa.
} 
EB simplex-are clinically and histologically distinguishable and present a variable expression ranging from mild blistering of the hands and feet to severe generalized involvement (2).

RDEB characteristically begins at birth or in infancy with blistering of the skin and mucous membranes following trivial injury. Its clinical severity ranges from debilitating to mutilating or fatal. Both ultrastructural studies, showing collagen degradation and macrophagic ingestion of collagen in RDEB skin $(3,4)$, and short-term organ cultures of RDEB skin, showing increased collagenase in blistered $(5,6)$ and uninvolved (5) areas, have suggested that mechanisms involved in collagen breakdown might be important in this disease. Further evidence of a pathogenic role for collagenase was obtained with the demonstration of up to a 12 fold increase in tissue levels of immunoreactive collagenase in blistered and nonblistered skin (7). Thus, a fundamental aberration in collagenase expression, as manifested by increased synthesis and/or enzymic activity, would seem to provide a plausible mechanism for the excessive blistering and tissue fragility that clinically characterize RDEB.

In this regard, using biosynthetic techniques, we have shown that RDEB fibroblasts synthesized increased amounts of collagenase in vitro $(8,9)$. This biochemical phenotype was unique for RDEB, since skin fibroblasts derived from patients with other genetic types of EB did not display increased synthesis of the enzyme $(8,9)$. Interestingly, additional studies using partially purified collagenases from two patients with RDEB provided preliminary evidence for the existence of an aberrant form of the enzyme (10). Taken together these observations suggested the intriguing possibility that RDEB could be biochemically characterized by the increased synthesis of a structurally abnormal form of collagenase.

In this report we have used fibroblasts derived from a clinically typical patient with RDEB whose cells have been documented by biosynthetic methods to have increased synthesis of collagenase (9). Our major aims were twofold: $(a)$ to develop reproducible methods for purifying the putatively mutant RDEB procollagenase to homogeneity and $(b)$ to compare the resultant enzyme with the collagenase derived from normal skin fibroblasts in terms of biochemical and immunologic parameters.

\section{METHODS}

Fibroblast cultures. RDEB fibroblast cultures were established from skin punch biopsies after obtaining informed consent. All biopsies were taken from normal-appearing posterior trunk skin. The RDEB patient, a 4-yr-old male, displayed all of the characteristic features of RDEB (2) including onset of widespread blistering at birth, oral mucosal and esophageal lesions, dystrophic nails and teeth, scarring, milia, flexural contractures, and acquired syndactyly. His cells have been used previously in biosynthetic studies to demonstrate enhanced collagenase synthesis (see ref. 9, cell strain WUE 76114). Control skin fibroblast cultures (cell strain CRL 1224) were purchased from the American Type Culture Collection (Rockville, MD).

All fibroblasts were subcultivated at $37^{\circ} \mathrm{C}$ in glass roller bottles $\left(1585 \mathrm{~cm}^{2}\right.$, Bellco Glass, Inc., Vineland, $\left.\mathrm{NJ}\right)$ in 50 $100 \mathrm{ml}$ of Dulbecco's modified Eagle's medium-high glucose + glutamine containing $0.03 \mathrm{M} \mathrm{N}$-2-hydroxyethyl-piperazine- $N^{\prime}$-2-ethanesulfonic acid (Hepes) buffer ( $\left.\mathrm{pH} 7.6\right), 20 \%$ fetal calf serum, and $200 \mathrm{U}$ of penicillin and $200 \mu \mathrm{g}$ of streptomycin $/ \mathrm{ml}$. At visual confluence, the cells were put through several 24-h cycles of maintenance in serum-free medium as described previously $(11,12)$. After each 24 -h cycle, the serum-free medium was made $0.05 \mathrm{M}$ in Tris-hydroxyaminomethane- $\mathrm{HCl}(\mathrm{Tris}-\mathrm{HCl})(\mathrm{pH} 7.5)$ and concentrated $10-$ to 20 -fold by vacuum dialysis using a hollow fiber device. Serum-containing medium was processed separately for purification (see below) and was buffered with $0.05 \mathrm{M}$ Tris$\mathrm{HCl}(\mathrm{pH} 7.5)$ for storage without concentration. All medium was stored at $-20^{\circ} \mathrm{C}$ until processed for purification.

Collagenase assay. The activation of latent collagenase was accomplished proteolytically with trypsin at $25^{\circ} \mathrm{C}$ for $10 \mathrm{~min}$ as described previously $(11,12)$. For each proenzyme preparation, a range of trypsin concentrations, usually $0.1-$ $5.0 \mu \mathrm{g}$ trypsin per 50- $\mu \mathrm{l}$ sample, was used to ensure that maximal collagenase activity was achieved. After trypsin preincubation, at least a fourfold molar excess of soybean trypsin inhibitor was added to inhibit further trypsin activity. The mixture was then assayed for collagenase activity at $37^{\circ} \mathrm{C}$ in $0.05 \mathrm{M}$ Tris- $\mathrm{HCl}(\mathrm{pH} 7.5)$ in the presence of 10 $\mathrm{mM} \mathrm{CaCl}{ }_{2}$ using reconstituted $\left[{ }^{14} \mathrm{C}\right]$ glycine-labeled guinea pig skin collagen fibrils as a substrate gel (13). The ${ }^{14} \mathrm{C}$-collagen had a specific activity of $\sim 30,000 \mathrm{cpm} / \mathrm{mg}$.

Other assays. Protein concentrations were determined spectrophotometrically by the method of Groves et al. (14) using bovine serum albumin as a standard. Statistical analysis was performed using Student's $t$ test.

Purification procedures. Electrophoretically homogeneous normal human skin fibroblast procollagenase was prepared as detailed previously by Stricklin et al. (12) for comparison with the putatively mutant RDEB procollagenase. Concentrated serum-free RDEB fibroblast culture medium, typically an amount harvested from $25-50$ roller bottles, was made $1 \mathrm{mg} / \mathrm{ml}$ in bovine serum albumin and dialyzed at $4^{\circ} \mathrm{C}$ against several large volumes of a buffer containing 10 $\mathrm{mM}$ Tris- $\mathrm{HCl}$ (pH 7.5) with $10 \mathrm{mM} \mathrm{CaCl}{ }_{2}$ (Tris- $\mathrm{CaCl}_{2}$ buffer). This material was then applied at $4^{\circ} \mathrm{C}$ at a flow rate of $\sim 50 \mathrm{ml} / \mathrm{h}$ to a $1.5 \times 15-\mathrm{cm}$ column of carboxymethylcellulose (CM-cellulose, CM-52, Whatman, Inc., Clifton, NJ) equilibrated in the same buffer. After the absorbance at 230 $\mathrm{nm}$ returned to base line, a $300-\mathrm{ml}$ linear gradient of 0.0 to $0.3 \mathrm{M} \mathrm{NaCl}$ in Tris- $\mathrm{CaCl}_{2}$ buffer was used to elute the protein.

Serum-containing RDEB fibroblast culture medium was processed in a slightly different manner. Initially 8-10 liter of crude medium obtained from $80-100$ confluent $1585-\mathrm{cm}^{2}$ roller bottles of cells were brought to $55 \%$ saturation with $\left(\mathrm{NH}_{4}\right)_{2} \mathrm{SO}_{4}$ at $4^{\circ} \mathrm{C}$, and the precipitate was harvested by centrifugation at $9,000 \mathrm{~g}$. The supernatant was discarded, and the precipitate was dissolved in the smallest practicable volume of Tris- $\mathrm{CaCl}_{2}$ buffer, usually $200-300 \mathrm{ml}$ per 10 -liter batch, and dialyzed against the same buffer. The sample was then applied at $4^{\circ} \mathrm{C}$ at a flow rate of $\sim 80 \mathrm{ml} / \mathrm{h}$ to a 2.5 $\times 20$-cm column of CM-cellulose equilibrated in Tris- $\mathrm{CaCl}_{2}$ 
buffer. After the absorbance at $280 \mathrm{~nm}$ returned to base line, elution of the bound protein was accomplished with a stepwise increase in $\mathrm{NaCl}$ concentration to $0.4 \mathrm{M}$.

The partially purified procollagenase preparations were next applied to two columns, each $1.5 \times 100 \mathrm{~cm}$, packed in series with Sephadex G-100 (Pharmacia Fine Chemicals, Piscataway, NJ) which had been previously equilibrated with $50 \mathrm{mM}$ Tris- $\mathrm{HCl}$ (pH 7.5) containing $10 \mathrm{mM} \mathrm{CaCl}$ and $0.15 \mathrm{M} \mathrm{NaCl}$ (Tris- $\mathrm{CaCl}_{2}-\mathrm{NaCl}$ buffer). Proteins were filtered at a rate of $8 \mathrm{ml} / \mathrm{h}$.

Electrophoresis. Sodium dodecyl sulfate (SDS) gel electrophoresis was performed by the method of King and Laemmli (15) using a 10 or $15 \%$ gel. Proteins were stained with Coomassie Brilliant Blue.

Determination of kinetic constants. Kinetic properties of RDEB collagenase including specific activity, substrate binding constants $\left(K_{m}\right)$, catalytic rates $\left(k_{c a t}\right)$, energy of activation $\left(\mathrm{E}_{\mathrm{act}}\right)$, and the deuterium isotope effect $\left(\mathrm{kH}_{2} \mathrm{O} / \mathrm{kD}_{2} \mathrm{O}\right)$ were determined as previously described by Welgus et al. $(16,17)$ for the normal human skin fibroblast collagenase. Briefly, trypsin-activated RDEB collagenase was assayed at $25^{\circ} \mathrm{C}$ with the five genetically distinct human collagens in solution. Quantitation of the reaction was accomplished by densitometry of the Coomassie Blue-stained collagen degradation products separated by SDS gel electrophoresis (16). Under these conditions, collagenase follows classical $\mathrm{Mi}$ chaelis-Menton kinetics (16) and thus both $K_{\mathrm{m}}$ and $\mathrm{k}_{\mathrm{cat}}$ can be determined. In addition, assays using fibrillar collagen were performed at various temperatures and an Arrhenius plot was produced in order to derive an energy of activation $\left(\mathrm{E}_{\mathrm{act}}\right)$. Lastly, fibrillar collagen assays were performed in solutions consisting of $90 \%$ deuterium oxide $\left(\mathrm{D}_{2} \mathrm{O}\right)$ and the reaction velocity compared to those obtained in $\mathrm{H}_{2} \mathrm{O}$.

Isoelectric focusing. Isoelectric focusing was performed either in a sucrose density gradient stabilized column (LKB Instruments, Inc., Rockville, MD) or horizontally on acrylamide slabs using the LKB Multiphor apparatus. 2\% Pharmalyte (Pharmacia Fine Chemicals, Uppsala, Sweden), $\mathbf{p H}$ $3.5-10.0$, and $6 \mathrm{M}$ urea were incorporated in the liquid column. Precast acrylamide slabs ( $\mathrm{pH} \mathrm{3-10)}$ were also obtained from LKB Instruments, Inc. The liquid column was drained and proteins were monitored at $280 \mathrm{~nm}$. Coomassie Brilliant Blue was used to detect the protein bands in the acrylamide slab.

Amino acid analysis. Amino acid analyses were performed by the method of Spackman et al. (18) with a Beckman 119C automated amino acid analyzer employing a single column. Samples were hydrolyzed in vacuo in $6 \mathrm{~N}$ $\mathrm{HCl}$ at $110^{\circ} \mathrm{C}$ for 24,48 , or $72 \mathrm{~h}$. Tryptophan was determined separately by the method of Simpson et al. (19) and half-cystine was determined as cysteic acid as described by Moore (20).

Cyanogen bromide digestion. Immediately following purification, procollagenase was lyophilized and redissolved in $1-2 \mathrm{ml}$ of deionized $8 \mathrm{M}$ urea to prevent degradation. Following exhaustive dialysis against $1 \mathrm{M}$ acetic acid at $4^{\circ} \mathrm{C}$, the sample was again lyophilized and redissolved in $70 \%$ formic acid $(1 \mathrm{mg} / \mathrm{ml})$. A 30 -fold weight excess of solid cyanogen bromide was added, and after incubation in the dark for $24 \mathrm{~h}$, the reaction mixture was diluted fivefold with water, flushed with $\mathrm{N}_{2}$, and lyophilized. SDS polyacrylamide gel electrophoresis was performed according to King and Laemmli (15) using $15 \%$ cylindrical acrylamide gels. Samples $(200 \mu \mathrm{g})$ were dissolved in $100 \mu \mathrm{l}$ of sample buffer containing $652 \mu \mathrm{g}$ of dithiothreitol and boiled for $5 \mathrm{~min}$ before electrophoresis.
Thermal stability. As a further probe to the structure of the RDEB procollagenase, we compared its thermal stability with that of the proenzyme harvested from control fibroblasts. For these experiments, the metal cofactor, $\mathrm{Ca}^{2+}$, which functions as a thermostabilizer of the enzyme (21), was removed by extensive dialysis at $0-2^{\circ} \mathrm{C}$ against $0.05 \mathrm{M}$ Tris-HCl (pH 7.5) with $0.15 \mathrm{M} \mathrm{NaCl}$ (Tris- $\mathrm{NaCl}$ buffer). $\mathrm{Ca}^{2+}$ was then restored in concentrations ranging from 0.1 to $10 \mathrm{mM}$ and the preparations were heated at $60^{\circ} \mathrm{C}$ for 0 $10 \mathrm{~min}(10)$. After this incubation, $\mathrm{Ca}^{2+}$ was added to each proenzyme preparation to reach a saturating concentration of $10 \mathrm{mM}$, and the mixture was briefly placed on ice prior to assay for residual collagenase activity as described above.

Affinity of collagenase for $\mathrm{Ca}^{2+}$. To assess the extrinsic metal cofactor requirements, $\mathrm{Ca}^{2+}$ was removed by exhaustive dialysis against $\mathrm{Tris}-\mathrm{NaCl}$ buffer at $4^{\circ} \mathrm{C}$. For kinetic analysis, $\mathrm{Ca}^{2+}$ (as $\mathrm{CaCl}_{2}$ ) was replaced in varying concentrations prior to assay (10). The apparent $K_{m}$ for $\mathrm{Ca}^{2+}$ was determined from double reciprocal plots using a programmable calculator.

Preparation of antiserum to $R D E B$ procollagenase. Antiserum to the RDEB procollagenase was prepared essentially as described for preparation of the antiserum to normal human skin procollagenase (22). Briefly, adult male white rabbits weighing $2-3 \mathrm{~kg}$ were immunized initially with $\sim 0.5 \mathrm{mg}$ of purified proenzyme emulsified in complete Freund's adjuvant. Rabbits were given booster injections of $0.25 \mathrm{mg}$ of collagenase after $4 \mathrm{wk}$ and test bled $1 \mathrm{wk}$ later. Rabbits that showed the presence of precipitating antibodies were again boosted and after bleeding, the sera were pooled and taken to $33 \%$ saturation with $\left(\mathrm{NH}_{4}\right)_{2} \mathrm{SO}_{4}$ at $0^{\circ} \mathrm{C}$ in order to obtain the $\gamma$-globulin fraction. The resulting precipitate was dissolved in Tris- $\mathrm{NaCl}$ buffer in a volume equal to the initial serum volume. Residual $\left(\mathrm{NH}_{4}\right)_{2} \mathrm{SO}_{4}$ was removed by dialysis against Tris- $\mathrm{NaCl}$ buffer. A preimmune rabbit $\gamma$ globulin preparation was made in the same manner

Immunodiffusion and enzyme inhibition by antibody. Immunologic comparison of the RDEB and control procollagenases was performed using gel diffusion in $0.75 \%$ Ionagar (Colab Laboratories, Glenwood, IL) as described by Ouchterlony (23). Inhibition of collagenase activity by antibody was performed by preincubating anti-collagenase $\gamma$-globulin in dilutions ranging from undiluted to $1 / 64$ with a constant amount of procollagenase for $2 \mathrm{~h}$ at $37^{\circ} \mathrm{C}$ before assaying for residual enzyme activity. Controls were routinely included which contained an equal concentration of preimmune rabbit $\gamma$-globulin.

Quantitative precipitation of enzyme by antiserum. To compare the relative specificity of the anti-control collagenase serum for its immunogen and for the RDEB collagenase and that of the anti-RDEB collagenase serum for its immunogen and for the control collagenase, we carried out a quantitative precipitin analysis. The equivalence point of each reaction was determined by titrating a constant amount of antiserum against an increasing amount of electrophoretically homogeneous carrier enzyme. The mixture was incubated in disposable plastic tubes at $37^{\circ} \mathrm{C}$ for $30 \mathrm{~min}$ followed by an overnight incubation at $4^{\circ} \mathrm{C}$. The resulting precipitates were harvested by centrifugation and washed twice with Tris- $\mathrm{NaCl}$ buffer containing $0.5 \%$ bovine serum albumin as described previously (24). For these studies the efficiency of the precipitation was monitored by the addition of a constant tracer amount of $\left[{ }^{3} \mathrm{H}\right]$ leucine-labeled normal or RDEB procollagenase (24). The ${ }^{3} \mathrm{H}$-labeled procollagenase was prepared biosynthetically by incorporating $\left[{ }^{3} \mathrm{H}\right]$ leucine into the culture medium as described earlier ( 8 ) followed by purification of the ${ }^{3} \mathrm{H}$-labeled proenzyme as detailed above. 


\section{RESULTS}

Purification. To address the question of whether the RDEB collagenase might be structurally abnormal, we used fibroblasts grown in mass culture for purification of the putatively mutant enzyme. Initially, we used only serum-free RDEB fibroblast culture medium for purification to minimize contamination with extraneous proteins. Since our previous studies of normal human skin fibroblast collagenase (12) indicated that the critical step in purification was cation-exchange chromatography, we used CM-cellulose chromatography as a first step with starting buffer concentrations identical to those used for purification of the normal proenzyme, i.e., $10 \mathrm{mM}$ Tris- $\mathrm{HCl}$ containing $0-0.1$ $\mathrm{mM} \mathrm{CaCl}$ (12). Although these conditions resulted in efficient binding of RDEB proenzyme to the ion exchanger, in contrast to the stability of the normal enzyme (12), we encountered almost complete loss of activity, presumably due to the marked lability of the RDEB enzyme in the low $\mathrm{Ca}^{2+}$ concentrations. Accordingly, we next attempted to enhance the yields by raising the $\mathrm{Ca}^{2+}$ concentration of the starting buffer. As shown in Fig. 1A, the RDEB proenzyme, but few other proteins, bound to CM-cellulose in the presence of $10 \mathrm{mM} \mathrm{Ca}{ }^{2+}$, a chromatographic condition which was strikingly at variance with the normal procollagenase, where the inclusion of even $1 \mathrm{mM} \mathrm{Ca}^{2+}$ in the starting buffer resulted in failure of the enzyme to bind to the matrix. After gradient elution from CMcellulose (Fig. 1A), the RDEB proenzyme preparation was next applied to a gel filtration column of Sephadex G-100 (Fig. 1B) to complete the purification.

A similar series of steps was used for the purification of the RDEB procollagenase from serum-containing culture medium (Fig. 2). The major differences were twofold. First, $55 \%$ ammonium sulfate precipitation was used for concentration of the large volumes of medium ( $\sim 10$ liter $)$ prior to CM-cellulose chromatography, and second, a stepwise elution of the enzyme bound to CM-cellulose (Fig. 2A) was used rather than a gradient. This allowed us to elute the enzyme rapidly and in small enough volumes (e.g., fractions 96-99 in Fig. 2A) for direct application to the Sephadex G-100 (Fig. 2B).

After gel filtration and pooling of the fractions containing enzyme activity (e.g., fractions $44-51$ in Fig. 2B), the RDEB procollagenase preparation was examined by SDS polyacrylamide disc gel electrophoresis (Fig. 3A). The electrophoretically homogeneous RDEB enzyme was found to represent a set of two proenzymes (noted as " $U$ " in Fig. 3) of approximate $M_{r}$ of 60,000 and 55,000 . These forms were not subunits, but rather-in a situation analogous to the normal procollagenases $(12,22)$-represented two distinct

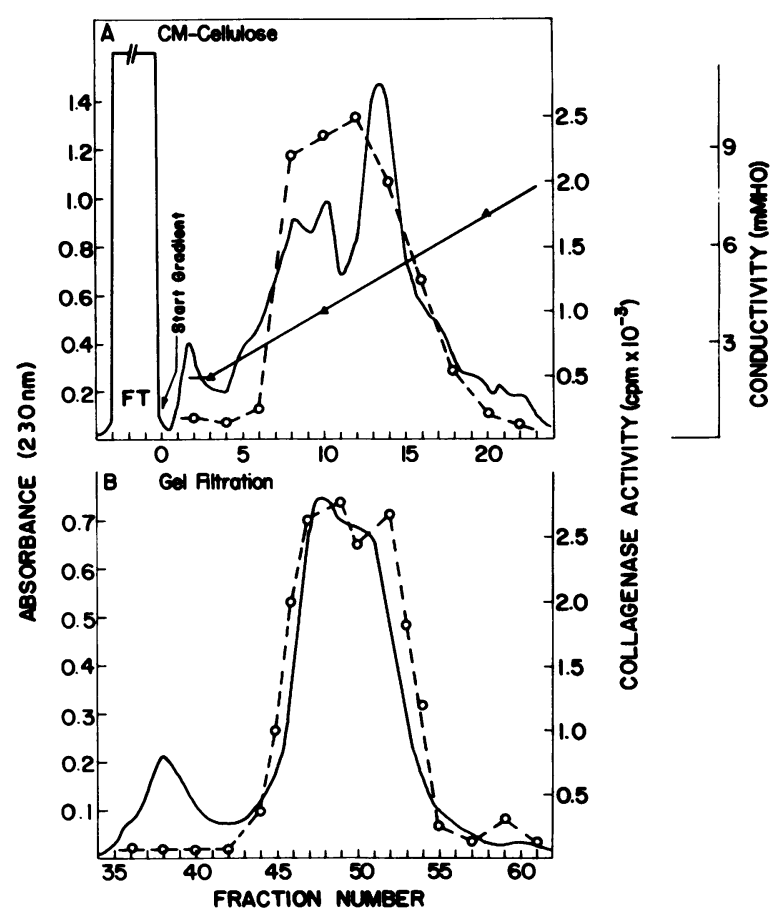

FigurE 1 Chromatography of serum-free RDEB culture medium. (A) Approximately 5 liter of serum-free medium was concentrated by ultrafiltration, made $1 \mathrm{mg} / \mathrm{ml}$ in bovine serum albumin and exhaustively dialyzed against Tris- $\mathrm{CaCl}_{2}$ buffer. It was then applied to a $1.5 \times 15-\mathrm{cm}$ column of $\mathrm{CM}$ 52 equilibrated in the same buffer at a flow rate of $50 \mathrm{ml} /$ h. After the absorbance at $230 \mathrm{~nm}$ returned to base line, a $300-\mathrm{ml}$ gradient of 0.0 to $0.3 \mathrm{M} \mathrm{NaCl}$ in Tris- $\mathrm{CaCl}_{2}$ buffer was applied to elute the protein. Aliquots of the fractions were assayed as described in Methods and tubes 7-16 were pooled. (B) The enzyme pool from ion-exchange chromatography was concentrated by ultrafiltration to $\sim 15-20 \mathrm{ml}$ and applied to a column $1.5 \times 200-\mathrm{cm}$ of Sephadex G-100 equilibrated in 0.05 Tris- $\mathrm{HCl}, \mathrm{pH} 7.5$, containing $0.01 \mathrm{M}$ $\mathrm{CaCl}_{2}$ and $0.15 \mathrm{M} \mathrm{NaCl}$ and flowing at $8 \mathrm{ml}$ per h. Fractions were assayed as in $A$. Tubes $45-54$ constituted the enzyme pool. Absorbance $230 \mathrm{~nm} \mathrm{(-);} \mathrm{Collagenase} \mathrm{activity}$ (O-- $-\mathrm{O})$; conductivity $(\boldsymbol{\Delta}-\mathbf{\Delta})$.

holoenzymes. These proenzyme forms could be proteolytically activated by trypsin to forms $\sim 10,000$ daltons less than their respective precursors (not shown). As in the case of the normal enzyme (12), a small amount of species corresponding in $M_{r}$ to the trypsin-activated forms could be observed in some of the preparations (noted as "L" in Fig. 3). Fig. 3B demonstrates the electrophoretic appearance of the purified RDEB collagenase in an SDS slab gel system. In this case, although the gel was overloaded with protein $(85 \mu \mathrm{g})$ in an attempt to detect minor contaminants, only the same collagenase species were found. The limits of this system in our laboratory are $0.1-0.2 \mu \mathrm{g}$ of protein; thus, by this criterion the RDEB collagenase 


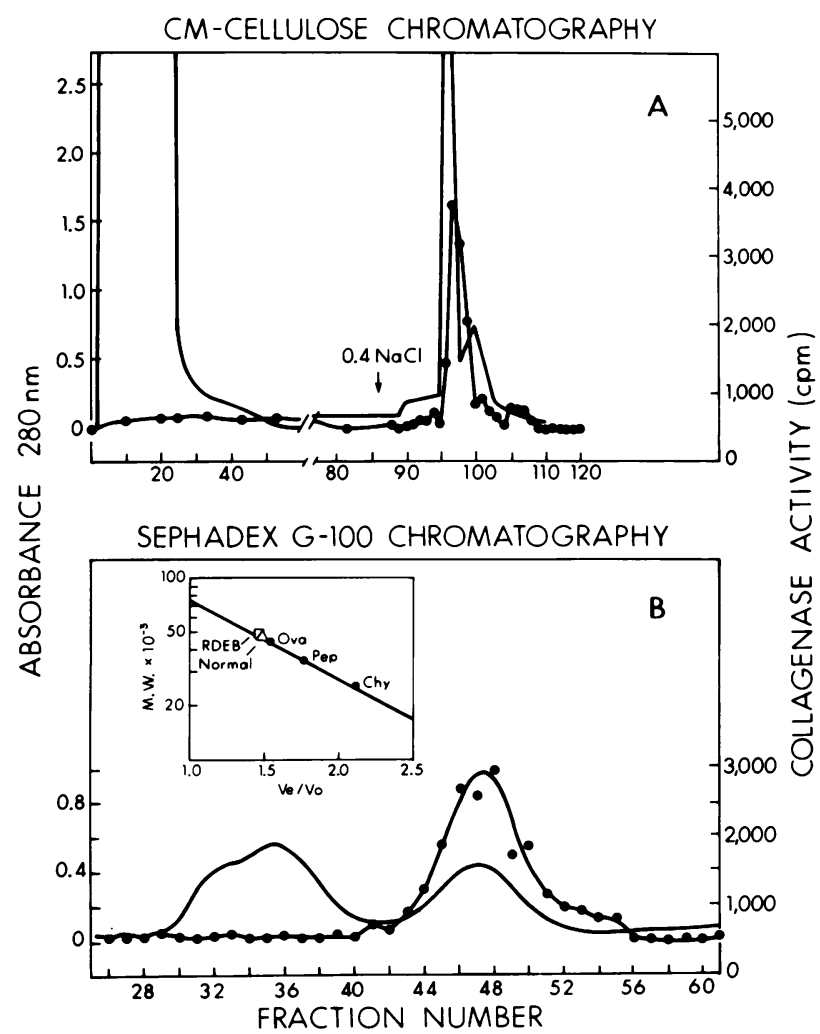

FIgURE 2 Chromatography of serum-containing RDEB collagenase. (A) 3.6 liter of serum-containing medium was salt precipitated, redissolved in $\mathrm{Tris}-\mathrm{CaCl}_{2}$ buffer, and dialyzed exhaustively against this buffer before application to a 2.5 $\times 12-\mathrm{cm}$ column of CM-52 equilibrated in the same buffer. A flow rate of $80 \mathrm{ml} / \mathrm{h}$ was maintained, the absorbance at $280 \mathrm{~nm}$ was monitored, and the column was kept at $4^{\circ} \mathrm{C}$. After the absorbance returned to base line, $0.4 \mathrm{M} \mathrm{NaCl}$ in Tris- $\mathrm{CaCl}_{2}$ buffer was used to elute the enzyme, which was assayed as previously described. Fractions 96-99 constituted the enzyme pool. (B) The above enzyme pool was applied, without concentration, to a $1.5 \times 200-\mathrm{cm}$ column of Sephadex G-100 equilibrated in $0.05 \mathrm{M}$ Tris- $\mathrm{HCl}$, pH 7.5, containing $0.01 \mathrm{M} \mathrm{CaCl}_{2}$, and $0.15 \mathrm{M} \mathrm{NaCl}$. A flow rate of 15 $\mathrm{ml} / \mathrm{h}$ was established as was a temperature of $4^{\circ} \mathrm{C} .20-\mathrm{min}$ fractions were collected as the absorbance was monitored at $280 \mathrm{~nm}$. Aliquots were assayed as previously described and tubes 45-51 were pooled. The column was calibrated for molecular weight using ovalbumin (Ova), pepsin (Pep), chymotrypsinogen (Chy), and Blue Dextran (see insert). Absorption $280 \mathrm{~nm}(\longrightarrow)$; collagenase activity $(\bullet-\bullet)$.

was $>99 \%$ electrophoretically homogeneous. SDS polyacrylamide gel electrophoresis revealed no significant differences in the $M_{\mathrm{r}}$ between comparable species of enzyme from the normal and RDEB sources. In addition no differences in electrophoretic mobility were observed upon reduction of the samples with dithiothreitol.

Table I summarizes the purification scheme for RDEB procollagenase. As seen with the two represen-

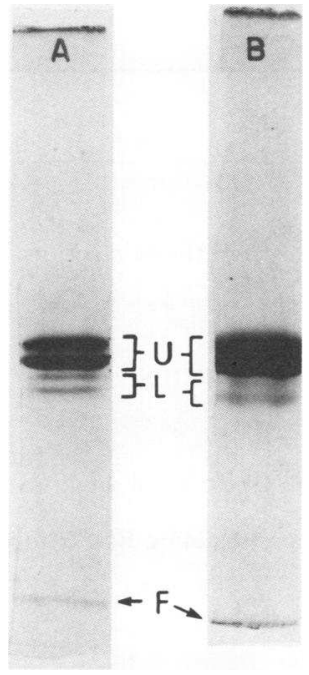

FIGURE 3 SDS polyacrylamide gel electrophoresis of purified RDEB collagenase. (A) $50 \mu \mathrm{g}$ of pure enzyme was applied to a $10 \%$ cylindrical acrylamide gel and electrophoresed as described in Methods. (B) $85 \mu \mathrm{g}$ of pure enzyme was applied to a $10 \%$ acrylamide slab gel. Samples were applied that contained both proenzyme (U) in its characteristic 60,000 - and 55,000-dalton doublet form as well as a small amount of the active enzyme (L) species. $F$ denotes the dye front.

tative purifications (from a total of 13) from serumfree medium, the RDEB collagenase proved to be significantly more labile to purification than the normal enzyme (12). Despite the fact that about twice as much pure enzyme protein could be obtained from the RDEB cultures as from the normal cultures, upon purification the yields and specific activities obtained with serum-free medium, even using optimum $\mathrm{Ca}^{2+}$ concentrations, were lower than normal. However, the use of serum-containing medium allowed us to approach values similar to those seen in the purification of the normal enzyme suggesting that the presence of other proteins during the initial steps of purification may have helped to stabilize the enzyme.

Biochemical properties. Amino acid analyses were performed on three different preparations using timed hydrolysates consisting of either mixed proenzyme species or mixed trypsin-activated enzymes for comparison with similar preparations of normal control collagenase (Table II). The RDEB procollagenase was quite similar to the normal proenzyme, although the data suggested that differences were present in the quantities of proline (Pro), glycine (Gly), half-cystine (Cys), methionine (Met), and tyrosine (Tyr) residues. The trypsin-activated enzymes from both sources were also quite similar. No glucosamine or galactosamine was present in enzyme from either source. 
TABLE I

Purification of RDEB Procollagenase

\begin{tabular}{|c|c|c|c|c|c|c|}
\hline Experiment & Source & Stage & Protein & $\begin{array}{l}\text { Specific } \\
\text { activity }\end{array}$ & Yield & Purification \\
\hline & & & mg & $\mu g / m i n / m g$ & $\%$ & fold \\
\hline \multirow[t]{3}{*}{ I } & Serum-free RDEB medium & Crude & 140.8 & 20 & 100 & - \\
\hline & & CM-52 & 3.2 & 45 & 5.2 & 2.3 \\
\hline & & GM-100 & 1.0 & 147 & 5.2 & 7.5 \\
\hline \multirow[t]{4}{*}{ II } & Serum free RDEB medium & Crude & 154.9 & 7 & 100 & - \\
\hline & & CM-52 & 3.6 & 420 & 100 & 60 \\
\hline & & G-100 & 0.6 & 503 & 28 & 72 \\
\hline & Serum-free control medium $\ddagger$ & - & - & 736 & - & - \\
\hline \multirow[t]{4}{*}{ III } & Serum-containing RDEB medium & Crude & 23,982 & $-\S$ & - & - \\
\hline & & CM-52 & 25.0 & 389 & 100 & - \\
\hline & & G-100 & 7.1 & 868 & $68^{\prime \prime}$ & 2.2 \\
\hline & Serum-containing control medium $\downarrow$ & - & - & 958 & - & - \\
\hline
\end{tabular}

- Specific activity represents micrograms of collagen solubilized at $37^{\circ} \mathrm{C}$ per minute per milligram enzyme protein.

\Values for activity represent those after complete purification (i.e., through the gel filtration step) (12).

\&eliable assays not possible due to high concentrations of serum.

"Values compared with preceding step only.

Fig. 4 shows the electrophoretic pattern of peptides produced upon simultaneous parallel cyanogen bromide digestions of the normal and RDEB procollagenases. The normal proenzyme, with nine resolved

TABLE II

Amino Acid Composition of RDEB Collagenase Species ${ }^{\circ}$

\begin{tabular}{|c|c|c|c|c|}
\hline \multirow[b]{2}{*}{ Residue } & \multicolumn{2}{|c|}{ RDEB } & \multicolumn{2}{|c|}{ Control } \\
\hline & Proenzyme & Active & Proenzyme & Active \\
\hline Lys & 33.1 & 26.3 & 32.2 & 20.7 \\
\hline His & 17.0 & 10.8 & 18.4 & 14.6 \\
\hline Arg & 25.8 & 19.9 & 27.1 & 21.5 \\
\hline Asx & 62.1 & 50.4 & 59.6 & 51.9 \\
\hline Glx & 56.2 & 42.4 & 53.4 & 41.9 \\
\hline Thr & 27.1 & 22.7 & 28.0 & 24.3 \\
\hline Ser & 27.2 & 24.0 & 27.4 & 25.5 \\
\hline Pro & 33.2 & 25.6 & 30.7 & 27.1 \\
\hline Gly & 42.8 & 34.8 & 39.3 & 36.1 \\
\hline Ala & 32.1 & 28.1 & 33.4 & 28.0 \\
\hline $1 / 2-$-Cys $\downarrow$ & 5.5 & 4.6 & 6.8 & 4.9 \\
\hline Val & 25.4 & 23.3 & 28.5 & 21.7 \\
\hline Met & 9.4 & 5.1 & 8.2 & 6.3 \\
\hline Ile & 19.4 & 18.9 & 19.7 & 18.6 \\
\hline Leu & 30.2 & 25.8 & 30.9 & 26.3 \\
\hline Tyr & 23.6 & 21.3 & 20.0 & 18.2 \\
\hline Phe & 34.6 & 32.0 & 35.9 & 29.2 \\
\hline Trp\$ & Trace & - & Trace & - \\
\hline
\end{tabular}

- Data are expressed as residues per molecule.

$\$$ Determined by performic acid oxidation.

$\S$ Determined by methanesulfonic acid hydrolysis. peptides, which we arbitrarily numbered from the top of the gel, revealed the presence of one major peptide (Fig. 4, normal gel, number 9) which was not seen in the RDEB procollagenase. In contrast, the RDEB procollagenase showed 10 resolved cyanogen bromide

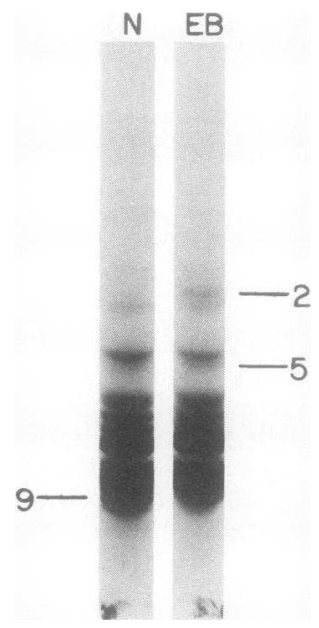

Figure 4 Cyanogen bromide peptides of normal and RDEB procollagenase. CNBr digestion was performed on $1-\mathrm{mg}$ aliquots of purified enzyme as described in Methods. 200- $\mu \mathrm{g}$ samples of normal (N) and RDEB (EB) origin were applied to cylindrical $15 \%$ acrylamide gels and electrophoresed as described in Methods. The peptides were arbitrarily numbered from the top of the gel for each enzyme source and the unique peptides in the normal (9) and RDEB digest (2, 5) are indicated. 
peptides, two of which, Fig. 4, EB gel, numbers 2 and 5 , were not present in the digest of the normal proenzyme. The remaining peptides were identical to those seen in the normal procollagenase. Although it is possible that some of these peptides could represent complex peptides, the pattern nevertheless represented a constant, distinct variation from the pattern observed in the normal enzyme under identical experimental conditions. The same cyanogen bromide peptide patterns were observed in two different normal and RDEB procollagenase preparations, indicating that the digestion and analysis systems were highly reproducible. In addition, the same patterns were observed whether reduction of disulfide bonds occurred before or after cyanogen bromide cleavage. Thus, these data, provide strong evidence for structural differences between the normal and RDEB procollagenases.

Isoelectric focusing was performed in two systems. Using horizontal acrylamide sheets, both the normal and RDEB proenzymes, when applied in native form, displayed extremely high isoelectric points $(>10)$. However, when $4 \mathrm{M}$ urea was incorporated as a denaturing agent, the normal and RDEB proenzymes focused in a rather diffuse band in the range of $\mathrm{pH}$ 6.5-7.0. The resolution was improved slightly by using a liquid column incorporating $6 \mathrm{M}$ urea (Fig. 5). In this case, in three different preparations the mean pI of the RDEB proenzyme was $7.2(7.2,7.3$, and 7.1$)$ compared to a pI of 6.7 (range, 6.7-6.8) for the normal

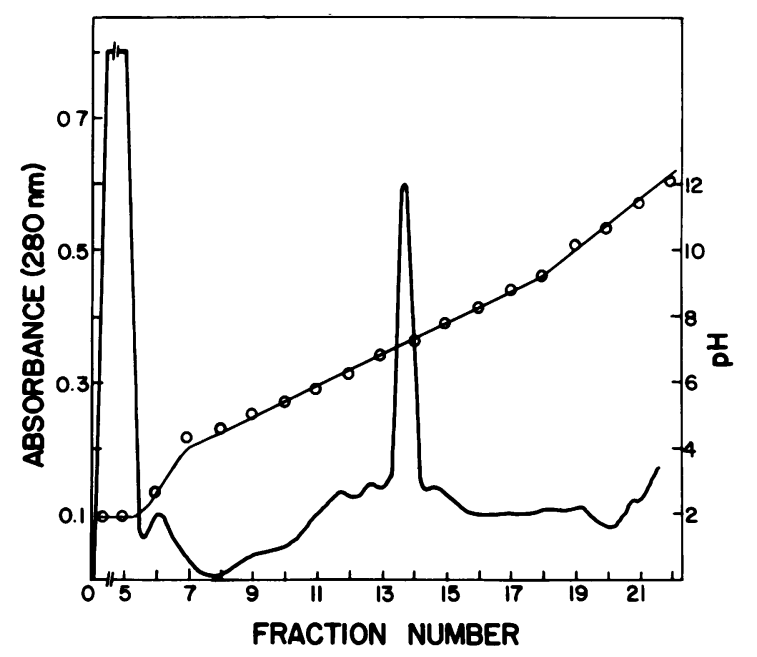

Figure 5 Isoelectric focusing of RDEB procollagenase. 5.5 $\mathrm{mg}$ of purified RDEB procollagenase was electrofocused in the presence of $6 \mathrm{M}$ urea and $2 \%$ ampholyte at $4^{\circ} \mathrm{C}$ for 48 h. A final voltage of $600 \mathrm{~V}$ was achieved in a sucrose density gradient-stabilized liquid column. The column was drained at $75 \mathrm{ml} / \mathrm{h}$ and the absorbance at $280 \mathrm{~nm}$ was recorded. The $\mathrm{pH}$ of each fraction was immediately determined. Absorbance $280 \mathrm{~nm}, \longrightarrow ; \mathrm{pH}, \mathrm{O} \longrightarrow \mathrm{O}$. proenzyme under the same conditions (22). These values indicate that the normal and RDEB procollagenases differed slightly in their isoelectric points; however, the poor behavior of these proteins, when subjected to this methodology (22), including a tendency to precipitate at or near the pI, precluded fine comparisons.

As a further probe to structural differences between the normal and RDEB procollagenases we examined their respective thermal stabilities (Fig. 6). Prior to exposing the proenzymes to the thermal insult, $\mathrm{Ca}^{2+}$, which functions as a thermostabilizing metal ion (21), was removed by exhaustive dialysis. After restoration of a saturating amount of $\mathrm{Ca}^{2+}(10 \mathrm{mM})$, the RDEB proenzyme lost $\sim 60 \%$ of its activity after $10 \mathrm{~min}$ at $60^{\circ} \mathrm{C}$ compared with an $\sim 20 \%$ loss of activity in the normal proenzyme (Fig. 6A). At a concentration of 0.1 $\mathrm{mM} \mathrm{Ca}{ }^{2+}$, well below the apparent $K_{\mathrm{m}}$ for $\mathrm{Ca}^{2+}$ (see below), the differences in the two enzymes were even greater (Fig. 6B). In this case the RDEB proenzyme lost almost $90 \%$ of its activity after $10 \mathrm{~min}$ at $60^{\circ} \mathrm{C}$, whereas the normal enzyme lost only $30 \%$ of its activity.

As noted previously, using partially purified RDEB procollagenases (10), these data suggested an altered affinity of the RDEB proenzyme for the metal cofac-

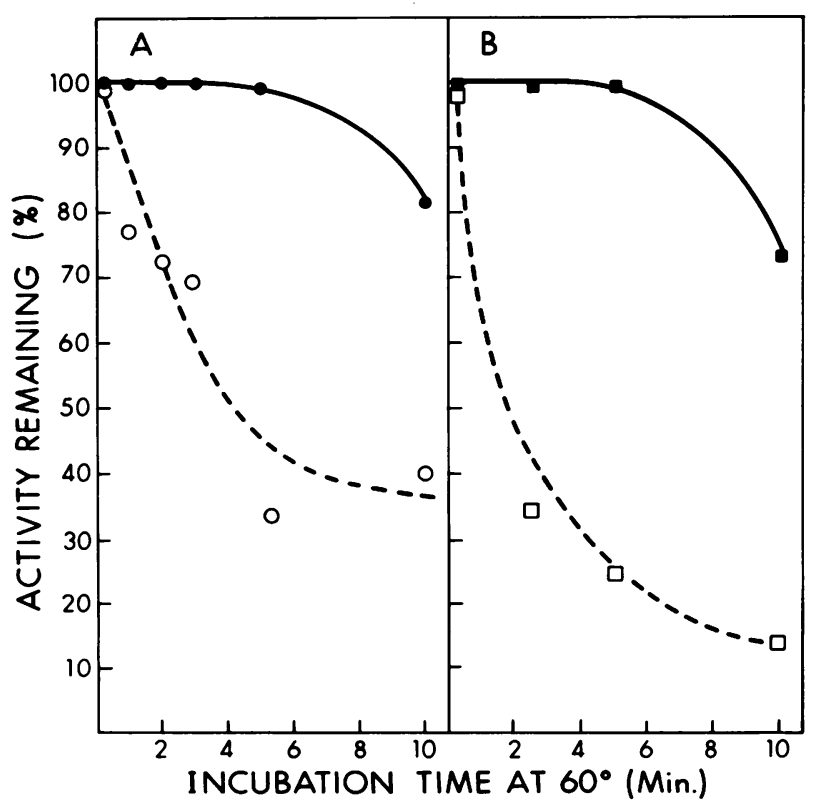

Figure 6 Thermal stability of normal and RDEB procollagenase. Proenzyme was made either $10 \mathrm{mM}$ (A) or $0.1 \mathrm{mM}$ (B) in $\mathrm{Ca}^{2+}$ and incubated for the indicated times at $60^{\circ} \mathrm{C}$. Following this, the $\mathrm{CaCl}_{2}$ concentration was adjusted to 10 $\mathrm{mM}$ and aliquots activated and assayed as described in Methods. (A) $10 \mathrm{mM} \mathrm{CaCl}_{2}$; Normal (O); RDEB (O). (B) 0.1

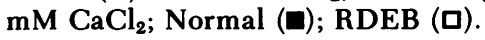


tor. Thus, again using the electrophoretically homogeneous RDEB collagenase, an apparent $K_{m}$ for $\mathrm{Ca}^{2+}$ was determined (Fig. 7). A value of $3.97 \pm 1.01 \mathrm{mM}$ (mean \pm SE) was obtained, significantly higher than the value of $1.06 \pm 0.09 \mathrm{mM}$ determined for the normal enzyme $(P<0.002)$.

Kinetic properties. A number of the kinetic parameters of normal collagenase have been determined $(16,17)$; thus, similar studies were performed using RDEB enzyme in order to assess the catalytic function of this protein. In the absence of a thermal insult and under saturating conditions for $\mathrm{Ca}^{2+}$ (i.e., $10 \mathrm{mM}$ ), the normal and RDEB proenzymes displayed essentially identical specific activities with average values of 818 $\mu \mathrm{g}$ guinea pig skin (type I) collagen fibrils solubilized at $37^{\circ} \mathrm{C} / \mathrm{min}$ per $\mathrm{mg}$ enzyme protein for the RDEB collagenase as compared with a value of 836 for normal enzyme. As seen in Table III, using the homologous human collagens in solution as substrates, both enzymes displayed similar binding constants $\left(K_{m}\right)$ as well as similar catalytic rates $\left(\mathbf{k}_{\text {cat }}\right)$. It is of interest that the substrate specificities were identical; thus, type III collagen was preferred to type I collagen. Type II collagen (cartilage) was a poor substrate, and types IV and $V$ collagens were not degraded by either enzyme.

Normal collagenase is characterized by an extraordinarily high $(101,050 \mathrm{cal})$ energy of activation $\left(\mathrm{E}_{\mathrm{Act}}\right)$; thus, its activity on fibrillar collagen triples with a $2^{\circ} \mathrm{C}$ increase in temperature (17). RDEB collagenase was found to have a similar high value of $95,600 \mathrm{cal}$. As shown previously (17); the normal enzyme also dis-

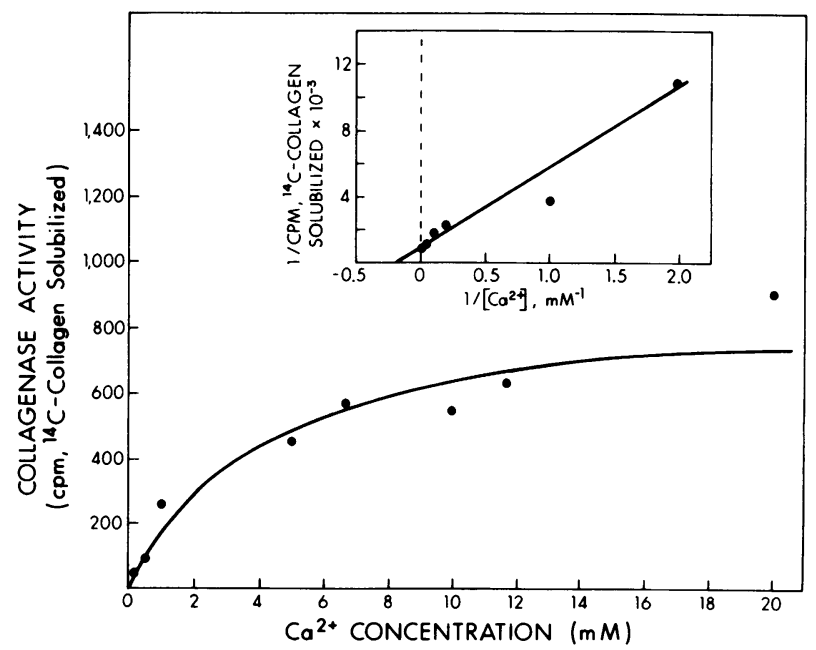

Figure 7 Affinity of RDEB procollagenase for $\mathrm{Ca}^{2+}$. After exhaustive dialysis at $4^{\circ} \mathrm{C}$ to remove $\mathrm{Ca}^{2+}$, the metal was restored in varying concentrations as described in Methods. Aliquots of $\mathrm{RDEB}$ procollagenase were then activated and assayed. A double-reciprocal plot (inset) was made to establish the apparent $K_{\mathrm{m}}$ value for $\mathrm{Ca}^{2+}(3.97 \mathrm{mM})$.
TABLE III

Kinetic Constants of Normal and RDEB Collagenase

\begin{tabular}{cccc}
\hline \multirow{2}{*}{ Enzyme } & $\begin{array}{c}\text { Collagen } \\
\text { substrate }\end{array}$ & $\kappa_{\mathbf{m}}$ & $k_{\text {cot }}$ \\
\hline \multirow{3}{*}{ RDEB } & & $\mu M$ & per $h$ \\
& Human I & 1.1 & 58.4 \\
& II & 1.9 & 1.3 \\
& III & 1.5 & 496.0 \\
& IV & $-{ }^{\circ}$ & - \\
Normal & V & - & - \\
& Human I & 0.8 & 53.4 \\
& II & 2.1 & 1.0 \\
& III & 1.4 & 565.0 \\
& IV & - & - \\
& V & - & - \\
\hline
\end{tabular}

- Denotes undetectable levels of activity against designated substrate.

plays a marked deuterium isotope effect $\left(\mathbf{k}_{\mathrm{H}_{2} \mathrm{O}} / \mathbf{k}_{\mathrm{D}_{2} \mathrm{O}}\right.$ $=$ in $90 \% \mathrm{D}_{2} \mathrm{O}$ ) on collagen fibrils, which suggests that hydrolysis of the collagen peptide bond is involved in the rate limiting step of the reaction. $A \mathbf{k}_{\mathrm{H}_{2} \mathrm{O}} / \mathbf{k}_{\mathrm{D}_{2} \mathrm{O}}$ of 10 in $90 \% \mathrm{D}_{2} \mathrm{O}$ was obtained for the RDEB collagenase, indicating yet another functional similarity to the normal enzyme.

Immunologic properties. Antiserum was produced in rabbits using the electrophoretically homogeneous mixed RDEB procollagenase species as the immunogen. Fig. 8 demonstrates the precipitin bands produced when the anti-RDEB and anti-normal procollagenase antisera were reacted in an Ouchterlony double diffusion system with the proenzymes from the

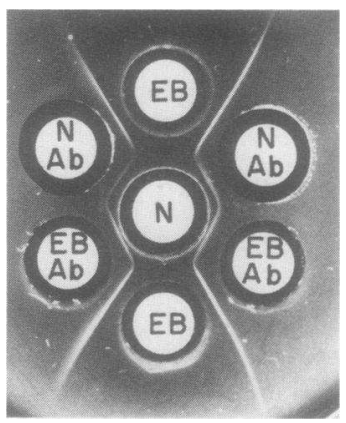

Figure 8 Immunodiffusion comparison of normal and RDEB procollagenases. Double diffusion was performed in agar as described in Methods. A reaction of identity is obtained in all combinations of antigen (normal and RDEB procollagenase) and antisera (anti-normal and anti-RDEB procollagenase). Normal procollagenase (N); RDEB procollagenase (EB); antinormal procollagenase antiserum (N Ab); Anti-RDEB procollagenase antiserum (EB Ab). 
two sources. In each case (i.e., anti-normal collagenase serum vs. normal collagenase and RDEB collagenase or anti-RDEB collagenase serum vs. RDEB collagenase and normal collagenase), a reaction of identity was obtained.

The specificities of the antisera were further defined by examining the ability of each to inhibit the activity of the two enzymes (Fig. 9). A $\gamma$-globulin preparation of the antiserum to the normal enzyme displayed a slight preference in inhibiting the activity of its normal collagenase immunogen with half-maximal inhibition occurring at a dilution of $\sim 1 / 32$ compared with halfmaximal inhibition of the RDEB enzyme between $1 /$ 16 and $1 / 32$ (Fig. 9A). Similarly, the anti-RDEB collagenase $\gamma$-globulin preferentially inhibited its enzyme antigen (Fig. 9B). In this case, half-maximal inhibition of the RDEB enzyme occurred at a dilution of $\sim 1 / 32$ compared with $\sim 1 / 16$ for the normal enzyme.

These subtle immunologic differences were further reflected in quantitative precipitin analysis (Fig. 10). The antiserum raised against the normal enzyme recognized both the normal and the RDEB enzymes equally as reflected by precipitation in approximately the same zone of equivalence (Fig. 10A). In contrast, the antiserum raised against the RDEB enzyme immunologically recognized its own antigen (i.e., RDEB enzyme) in an equivalence zone totally distinct from that seen with the normal enzyme (Fig. 10B). Here, the zone of equivalence for the RDEB enzyme antigen ranged from 0.06 to $0.5 \mu \mathrm{g}$ compared with precipitation at $<0.03 \mu \mathrm{g}$ of antigen in the case of the normal enzyme.

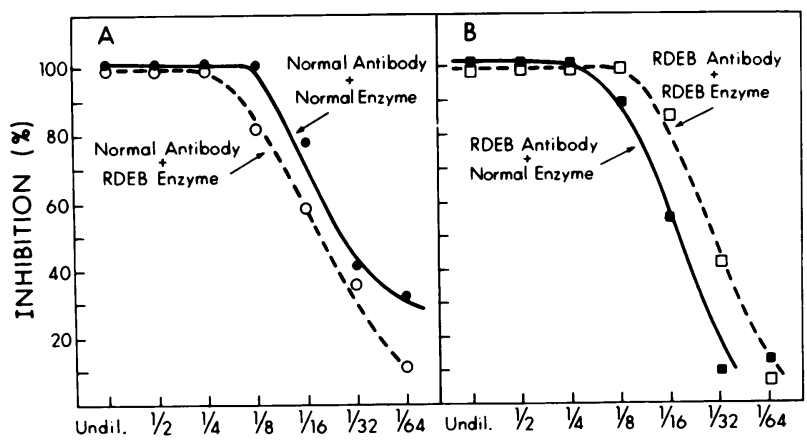

FIgURE 9 Inhibition of enzyme activity by anti-normal and anti-RDEB collagenase $\boldsymbol{\gamma}$-globulin. (A) Antinormal collagenase antibody was incubated at the indicated dilutions with a constant amount of procollagenase for $2 \mathrm{~h}$ at $37^{\circ} \mathrm{C}$. After this, the samples were assayed for residual activity. Enzyme used was normal (O) and RDEB (O). (B) Anti-RDEB collagenase antibody was incubated at the indicated dilutions with a constant amount of procollagenase for $2 \mathrm{~h}$ at $37^{\circ} \mathrm{C}$. After this, the samples were assayed for residual activity. Enzyme used was normal (ם) and RDEB ( $\square$ ).

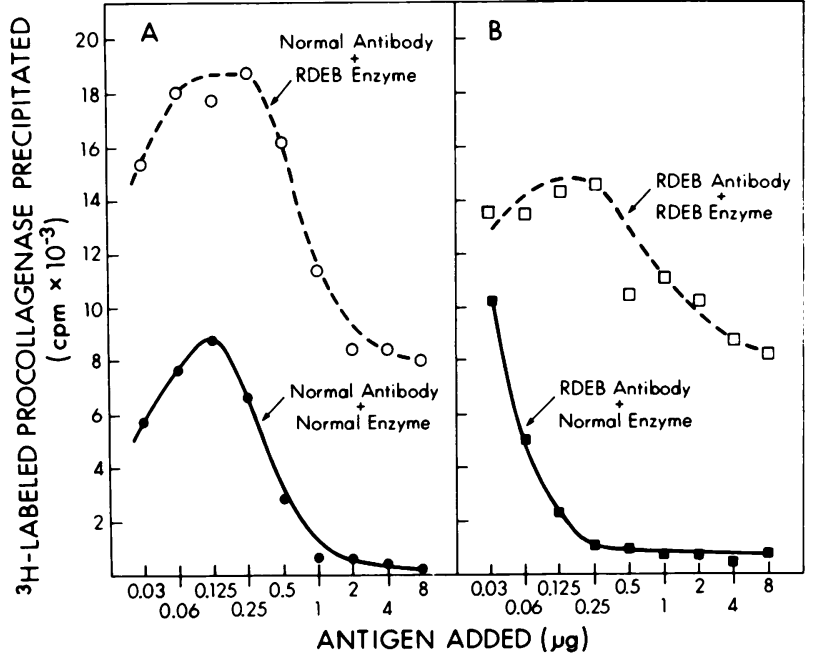

FIgURE 10 Quantitative precipitation of enzyme by antinormal and anti-RDEB procollagenase antiserum. (A) Antinormal collagenase antiserum was used to precipitate both normal and RDEB enzyme. ${ }^{3} \mathrm{H}$-labeled collagenase of either normal (O) or RDEB (O) origin was used as a marker of this process. (B) Anti-RDEB collagenase antibody was used to precipitate both normal and RDEB enzyme. ${ }^{3} \mathrm{H}$-labeled collagenase of either normal $(\square)$ or RDEB ( $\square$ ) origin was used as a marker of this process.

\section{DISCUSSION}

In this study we have used fibroblasts from a typical patient with RDEB, known to have increased synthesis of collagenase (9), to determine conclusively whether this disease, at least in some patients, is also associated with the biochemical phenotype of a structurally abnormal collagenase. In order to obtain the RDEB collagenase in a sufficiently pure form to carry out detailed comparative analyses with the normal enzyme, we modified the original three-step procedure of salt precipitation, ion exchange chromatography, and gel filtration chromatography to utilize conditions favorable to preservation of the activity of the RDEB enzyme. This resulted in RDEB enzyme preparations that were, by the criterion of SDS polyacrylamide gel electrophoresis, even using an "overloaded" slab gel system (Fig. 3B), >99\% homogeneous. The high degree of purity was further indicated $(a)$ by the fact that the antiserum raised against these preparations formed a single precipitin band when reacted both with pure and crude enzyme preparations and $(b)$ by the observation of kinetic parameters equivalent to those of the normal collagenase. Here, it is important to emphasize that, despite the lability of the RDEB enzyme, which could be detected using thermal insult as a probe, under standard assay conditions the purified RDEB enzyme displayed essentially the same kinetic 
properties as the control enzyme. Thus, both enzymes had the same specific activity as measured with fibrillar guinea pig skin (type I) collagen. More importantly, their binding constants, reaction rates, and collagen type specificities were very similar, if not identical, when measured against homologous substrates in solution, the human collagens (Table III).

The differences between the normal and RDEB collagenases, while in some cases subtle, were significant and reproducible. Chromatographically, the RDEB protein was remarkable in its ability to bind to CMcellulose at a $\mathrm{Ca}^{2+}$ concentration $(10 \mathrm{mM})$ at which no normal enzyme would bind. This property was of secondary benefit in that the high $\mathrm{Ca}^{2+}$ levels aided in stabilizing the enzyme. The fact that the pure RDEB procollagenase displayed a marked decrease in thermal stability (Fig. 6) can, in large part, be attributed to the decreased affinity for $\mathrm{Ca}^{2+}$ (Fig. 7), a metal cofactor known to stabilize the enzyme (21). The observation of these two properties, diminished thermal stability and decreased affinity for $\mathrm{Ca}^{2+}$, in the pure RDEB collagenase, thus lends considerable strength to our previous studies of two other RDEB collagenases in which similar properties were seen using only partially purified enzymes (10). The data further suggest that these biochemical abnormalities, coupled with overproduction of the enzyme $(8,9)$, might serve as a triad of in vitro genetic markers for RDEB.

While the present studies were derived from the cells of only one patient, they nonetheless appear to be representative of at least three patients from three different kindreds, who clinically and histologically have typical RDEB $(10,25)$. Indeed, in this patient and in one of those described previously (10), skin fibroblasts have been obtained at two different times, and in each case the increased synthesis of a structurally abnormal collagenase has been observed, thus further indicating a genetically stable trait.

Taken together, the biosynthetic (9) and purification data indicate that in RDEB there is increased synthesis of a structurally abnormal collagenase. Although the precise mutation leading to these combined features is unknown, the coexistence of a synthetic rate abnormality with a structural defect suggests a mutation spanning both regulatory and structural portions of the gene. Alternatively, it should be noted that although increased enzyme synthesis and/or activity have been observed in a variety of genetic circumstances, both primary and secondary mechanisms have been cited as the basis for such increases (26-32). In the situation perhaps most directly analogous to RDEB, examples of genetically increased synthesis of abnormal gene products, both intracellular and extracellular, have also been described (33-39). The most detailed study to date has been in the Hektoen variant of glucose-6- phosphate dehydrogenase in which a single amino acid substitution in the enzyme was found to be associated with a fourfold increase in synthesis of the gene product (37), representing a so-called quantitative mutant (38). As discussed by Yoshida (37) and in a later review by Goldberger (39), the data might also be interpreted as representing defective autogenous regulation of synthesis, a mechanism known to exist in both prokaryotic and eukaryotic systems (39). Indeed, recent studies using human skin fibroblasts indicate that the aminoterminal extension peptide of procollagen inhibits collagen synthesis both in intact cells (40) and in cell-free translation (41), suggesting that just such a mechanism exists in the same type of mesenchymal cells used for our studies.

\section{ACKNOWLEDGMENTS}

We gratefully acknowledge the excellent technical assistance of Mr. Stephen Johnson and Ms. Stephanie Kretow.

This work was supported by U. S. Public Health Service grants AM 19537, AM 12129, TO-AM 07284, 5K04 AM $00077, \mathrm{AM} 31078$, and RR 00036 from the National Institutes of Health.

\section{REFERENCES}

1. Gedde-Dahl, T., Jr. 1971. Epidermolysis bullosa. A Clinical, Genetic and Epidemiological Study. Johns Hopkins Press, Baltimore, MD.

2. Bauer, E. A., and R. A. Briggaman. 1979. The mechanobullous diseases (epidermolysis bullosa). In Dermatology in General Medicine. T. B. Fitzpatrick, A. Z. Eisen, K. Wolff, I. M. Freedberg, and K. F. Austen, editors. McGraw-Hill, Inc., New York. 2nd edition. 334-347.

3. Pearson, R. W. 1962. Studies on the pathogenesis of epidermolysis bullosa. J. Invest. Dermatol. 39: 551-575.

4. Hashimoto, I., U. W. Schnyder, I. Anton-Lamprecht, T. Gedde-Dahl, and S. Ward. 1976. Ultrastructural studies in epidermolysis bullosa hereditaria. III. Recessive dystrophic types with dermolytic blistering (Hallopeau-Siemens types and inverse type). Arch. Dermatol. Res. 256: 137-150.

5. Eisen, A. Z. 1969. Human skin collagenase: relationship to the pathogenesis of epidermolysis bullosa dystrophica. J. Invest. Dermatol. 52: 449-453.

6. Lazarus, G. S. 1972. Collagenase and connective tissue metabolism in epidermolysis bullosa. J. Invest. Dermatol. 58: 242-248.

7. Bauer, E. A., T. Gedde-Dahl, and A. Z. Eisen. 1977. The role of human skin collagenase in epidermolysis bullosa. J. Invest. Dermatol. 68: 119-124.

8. Bauer, E. A., and A. Z. Eisen. 1978. Recessive dystrophic epidermolysis bullosa. Evidence for increased collagenase as a genetic characteristic in cell culture. J. Exp. Med. 148: 1378-1387.

9. Valle, K-J., and E. A. Bauer. 1980. Enhanced biosynthesis of human skin collagenase in fibroblast cultures from recessive dystrophic epidermolysis bullosa. J. Clin. Invest. 66: 176-187.

10. Bauer, E. A. 1977. Recessive dystrophic epidermolysis bullosa: evidence for an altered collagenase in fibroblast cultures. Proc. Natl. Acad. Sci. U. S. A. 74: 4646-4650. 
11. Bauer, E. A., G. P. Stricklin, J. J. Jeffrey, and A. Z. Eisen. 1975. Collagenase production by human skin fibroblasts. Biochem. Biophys. Res. Commun. 64: 232-240.

12. Stricklin, G. P., E. A. Bauer, J. J. Jeffrey, and A. Z. Eisen. 1977. Human skin collagenase: isolation of precursor and active forms from both fibroblast and organ cultures. Biochemistry. 16: 1607-1615.

13. Nagai, Y., C. M. Lapiere, and J. Gross. 1966. Tadpole collagenase: preparation and purification. Biochemistry. 5: 3123-3130.

14. Groves, W. E., F. C. Davis, Jr., and B. Sells. 1968. Spectrophotometric determination of microgram quantities of protein without nucleic acid interference. Anal. Biochem. 22: 195-210.

15. King, J., and U. K. Laemmli. 1971. Polypeptides of the tail fibres of bacteriophage T4. J. Mol. Biol. 62: 465477.

16. Welgus, H. G., J. J. Jeffrey, and A. Z. Eisen. 1981. The collagen substrate specificity of human skin fibroblast collagenase. J. Biol. Chem. 256: 9511-9515.

17. Welgus, H. G., J. J. Jeffrey, and A. Z. Eisen. 1981. Human skin fibroblast collagenase. Assessment of activation energy and deuterium isotope effect with collagenous substrates. J. Biol. Chem. 256: 9516-9521.

18. Spackman, D. H., W. H. Stein, and S. Moore. 1958. Automatic recording apparatus for use in the chromatography of amino acids. Anal. Chem. 30: 1190-1206.

19. Simpson, R. J., M. R. Newberger, and T-Y. Liu. 1976. Complete amino acid analysis of proteins from a single hydrolysate. J. Biol. Chem. 251: 1936-1940.

20. Moore, S. 1963. On the determination of cystine as cysteic acid. J. Biol. Chem. 238: 235-237.

21. Seltzer, J. L., H. G. Welgus, J. J. Jeffrey, and A. Z. Eisen. 1976. The function of $\mathrm{Ca}^{2+}$ in the action of mammalian collagenases. Arch. Biochem. Biophys. 173: 355-361.

22. Stricklin, G. P., A. Z. Eisen, E. A. Bauer, and J. J. Jeffrey. 1978. Human skin collagenase: chemical properties of precursor and active forms. Biochemistry. 17: 23312337.

23. Ouchterlony, O. 1958. Diffusion-in-gel methods for immunological analysis. Prog. Allergy. 5: 1-78.

24. Valle, K-J., and E. A. Bauer. 1979. Biosynthesis of collagenase by human skin fibroblasts in monolayer culture. J. Biol. Chem. 254: 10115-10122.

25. Stricklin, G. P., and E. A. Bauer. 1981. Characterization of fibroblast collagenase from recessive dystrophic epidermolysis bullosa. Clin. Res. 29: 286 (Abstr.).

26. Wilson, J. W. 1979. Inherited elevation of alkaline phosphatase activity in the absence of disease. N. Engl. J. Med. 301: 983-984.

27. Tschudy, D. P., M. Valsamis, and C. R. Magnussen. 1975. Acute intermittent porphyria: Clinical and selected research aspects. Ann. Intern. Med. 83: 851-864.

28. Becker, M. A., L. J. Meyer, and J. E. Seegmiller. 1973. Purine overproduction in man associated with increased phosphoribosylpyrophosphate synthetase activity. Science (Wash., D. C.). 179: 1123-1126.

29. Becker, M. A., L. J. Meyer, and J. E. Seegmiller. 1973. Gout with purine overproduction due to increased phosphoribosylpyrophosphate synthetase activity. Am. J. Med. 55: 232-242.

30. Becker, M. A., P. J. Kostel, and L. J. Meyer. 1975. Human phosphoribosylpyrophosphate synthetase. Comparison of purified normal and mutant enzymes. J. Biol. Chem. 250: 6822-6830.

31. Martin, D. W., and B. A. Maler. 1976. Phosphoribosylpyrophosphate synthetase is elevated in fibroblasts from patients with the Lesch-Nyhan syndrome. Science (Wash., D. C.). 193: 408-411

32. Graf, L. J., J. A. McRoberts, T. M. Harrison, and D. W. Martin. 1976. Increased PRPP synthetase activity in cultured rat hepatoma cells containing mutations in the hypoxanthine-guanine phosphoribosyl-transferase gene. J. Cell. Physiol. 88: 331-342.

33. Yoshida, A., and A. G. Motulsky. 1969. A pseudocholinesterase variant (E Cynthiana) associated with elevated plasma enzyme activity. Am J. Hum. Genet. 21: 486498.

34. Rosen, F. S., C. A. Alper, J. Pensky, M. R. Klemperer, and V. H. Donaldson. 1971. Genetically determined heterogeneity of the $\mathrm{Cl}$ esterase inhibitor in patients with hereditary angioneurotic edema. J. Clin. Invest. 50: 2143-2149.

35. Laurell, A-B., J. Lindegren, I. Malmros, and H. Martensson. 1969. Enzymatic and immunochemical estimation of $\mathrm{Cl}$ esterase inhibitor in sera from patients with hereditary angioneurotic edema. Scand. J. Clin. Lab. Invest. 24: 221-225.

36. Shapira, E., Y. Ben-Yoseph, F. G. Eyal, and A. Russell. 1974. Enzymatically inactive red cell carbonic anhydrase B in a family with renal tubular acidosis. J. Clin. Invest. 53: 59-63.

37. Yoshida, A. 1970. Amino acid substitution (histidine to tyrosine) in a glucose-6-phosphate dehydrogenase variant (G6PD Hektoen) associated with over-production. J. Mol. Biol. 52: 483-490.

38. Sutton, H. E., and R. P. Wagner. 1975. Mutation and enzyme function in humans. Annu. Rev. Genet. 9: 187212

39. Goldberger, R. F. 1974. Autogenous regulation of gene expression. Science (Wash., D. C.). 183: 810-816.

40. Wiestner, M., T. Krieg, D. Horlein, R. W. Glanville, P. Fietzek, and P. K. Muller. 1979. Inhibiting effect of procollagen peptides on collagen biosynthesis in fibroblast cultures. J. Biol. Chem. 254: 7016-7023.

41. Paglia, L. M., M. Wiestner, M. Duchene, L. A. Ouellette, D. Horlein, G. R. Martin, and P. K. Muller. 1981. Effects of procollagen peptides on the translation of type II collagen messenger ribonucleic acid and on collagen biosynthesis in chrondrocytes. Biochemistry. 20: 35233527 . 